\title{
Does Quantitative Easing Work?
}

\author{
Salman Sakir ${ }^{1}$ \\ ${ }^{1}$ Independent Researcher, P. O. Box 20581, 322 Rideau Street, Ottawa, ON K1N 1A3, Canada. \\ Correspondence: Salman Sakir, Independent Researcher, P. O. Box 20581, 322 Rideau Street, Ottawa, ON K1N 1A3, \\ Canada. Tel: 1-613-400-3280. Email: salmansakir@gmail.com
}

Received: June 25, 2015

Accepted: July 9, $2015 \quad$ Available online: September 9, 2015

doi:10.11114/aef.v2i4.1077

URL: http://dx.doi.org/10.11114/aef.v2i4.1077

\begin{abstract}
This paper explores the effect of quantitative easing in the US. It discusses the financial crisis in the US economy and the policy response of the US government. It examines the effect of quantitative easing on various macroeconomic variables of the US economy. The paper researches the impact of quantitative easing on asset prices and inflation. It explores the effect of quantitative easing on employment in the US. Also, it investigates the impact of quantitative easing on GDP and economic growth in the US economy. It probes the effect of quantitative easing on income inequality in the US. Again, it scrutinizes the international spillovers of quantitative easing in the US. Finally, the paper inspects whether quantitative easing may lead to higher inflation in the future and, more importantly, may lead to another economic crisis in the future.
\end{abstract}

Keywords: US economy, Quantitative easing, US unemployment, US inflation, US debt, US GDP, US asset prices, US recession.

JEL Classification: E5, E6, F4, G1.

\section{Introduction}

A severe financial crisis started in the US in 2007 that spiraled into a global economic crisis. The financial crisis experienced in the US was the worst since the Great Depression. The policy response of the US government was to undertake massive quantitative easing in the hope of reinvigorating the US economy. The quantitative easing program led to changes in different sectors of the US economy. It is important to analyze the effectiveness of the quantitative easing program on the US economy. This paper examines the impact of quantitative easing on various macroeconomic variables.

The paper is structured as follows. Section 2 provides a brief description of the economic crisis while Section 3 explains how quantitative easing was used. Section 4 examines the impact of quantitative easing on gross domestic product followed by the effect on unemployment in Section 5. Sections 6 and 7 explore the effect of quantitative easing on inflation and US debt respectively. Section 8 probes the impact of quantitative easing on asset prices while Section 9 examines the experience of other countries with quantitative easing. Section 10 inspects whether quantitative easing may lead to economic crisis in the future that takes the paper to Section 11 which investigates whether quantitative easing is sufficient to ameliorate economic crisis. Finally, Section 12 provides some concluding remarks.

\section{The Economic Crisis}

The US economy started having problems in 2007 and, by 2008, the recession has already started. The subprime mortgage crisis resulted in economic chaos that ultimately led to a full-blown recession in the US economy. The subprime mortgage crisis started by banks providing high-risk mortgage to homeowners and which were, atleast, partially financed by financial inflow to the US from high-growth developing countries. The availability of foreign finance coupled with low interest rate encouraged people to purchase homes. Once the practice of risky lending and structured credit products reached the tipping point, interest rates started to increase while the prices of homes started to fall. This led to foreclosures and the economic crisis precipitated.

The bankruptcy of Lehman Brothers and near collapse of AIG introduced the severity of the economic crisis. This started the snowball effect of the recession. It shook the financial pillar of the US economy that later had a contagion effect on the rest of the economy. While prices of financial assets plummeted, the economic crisis had a significant adverse impact on US employment, gross domestic product, real estate and growth rate of the country. The 
unemployment rate increased significantly and many people joined the ranks of the unemployed. At the same time, the economy contracted, registering negative growth. Finally, real estate prices, which increased significantly before the advent of the recession, experienced substantial declines.

\section{How was Quantitative Easing Used?}

The US federal government used expansionary monetary policy as a policy response to counter the economic crisis. Coined as 'Quantitative Easing', the policy used by the Federal Reserve purchased US government bonds and mortgage-backed securities issued by government-sponsored enterprises like Fannie Mae and Freddie Mac. The quantitative easing program was conducted in three stages starting from late 2008 and ending in the later part of 2014. During these three phases, the Federal Reserve purchased US \$4.48 trillion of financial assets that increased the money supply in the US economy. In May 2015, almost 39 percent of Federal Reserve assets were mortgage-backed securities while 55 percent were U.S. Treasury securities.

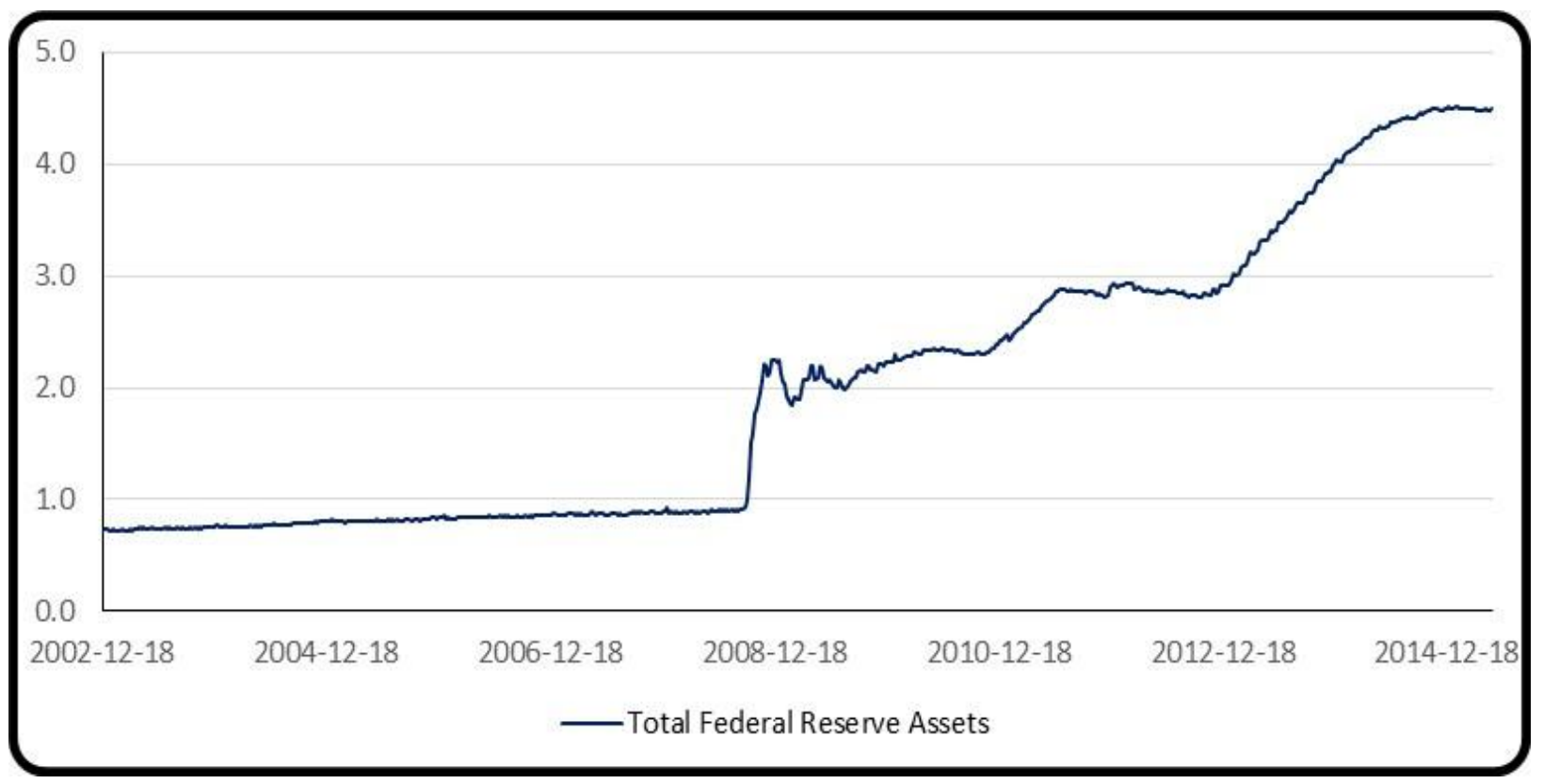

Source: Federal Reserve Bank of St. Louis

Figure 1. All Federal Reserve Banks - Total Assets, Eliminations from Consolidation, Trillions of Dollars, Weekly, Not Seasonally Adjusted 


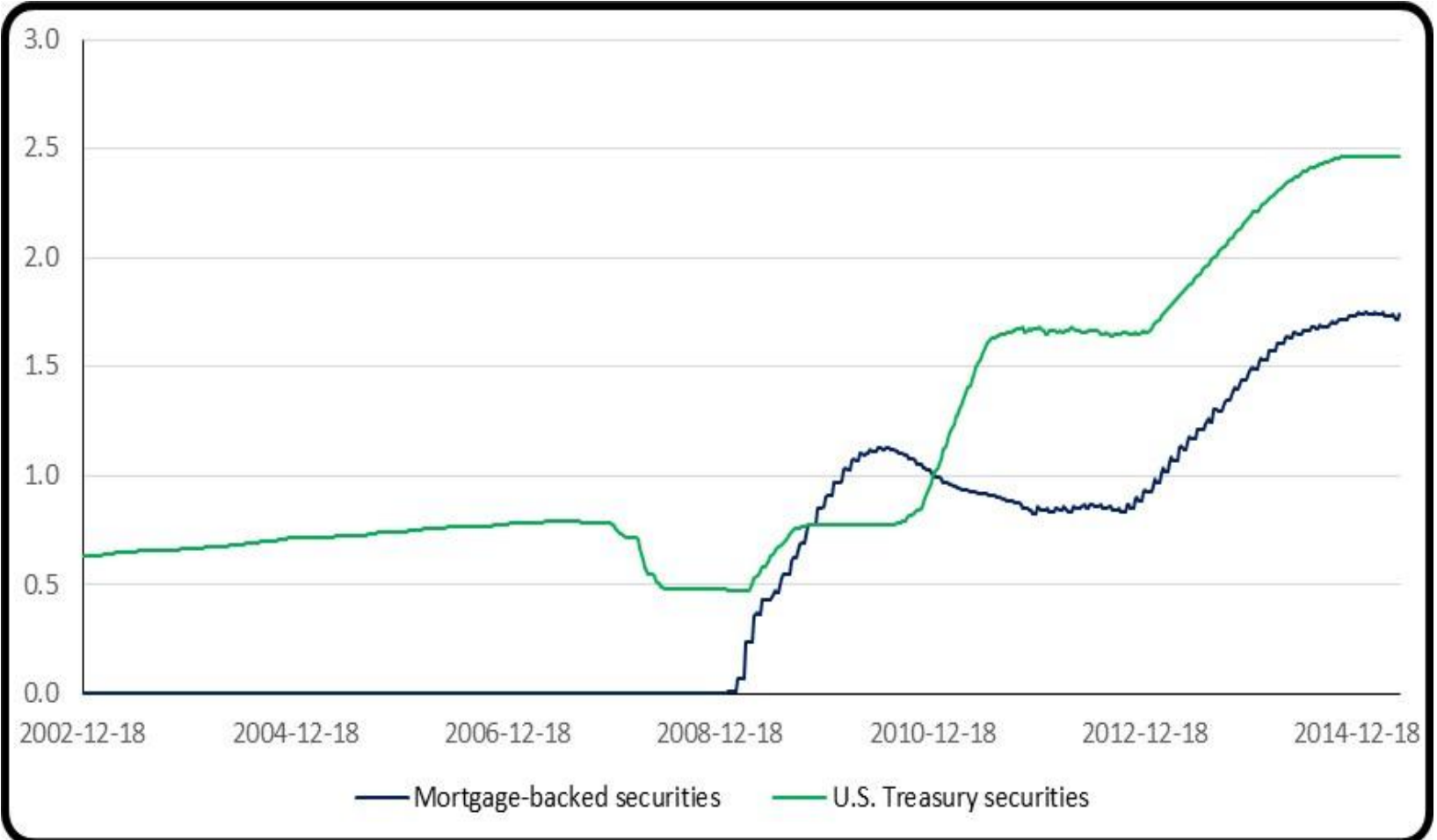

Source: Federal Reserve Bank of St. Louis

Figure 2. Mortgage-backed securities and U.S. Treasury securities held by the Federal Reserve: All Maturities, Millions of Dollars,

Weekly, Not Seasonally Adjusted

Along with buying financial assets, the Federal Reserve maintained a low interest rate which was very close to zero. The low interest rate was maintained to encourage individuals and businesses to purchase and invest in goods and services, with the objective of reinvigorating the recession-stricken economy.

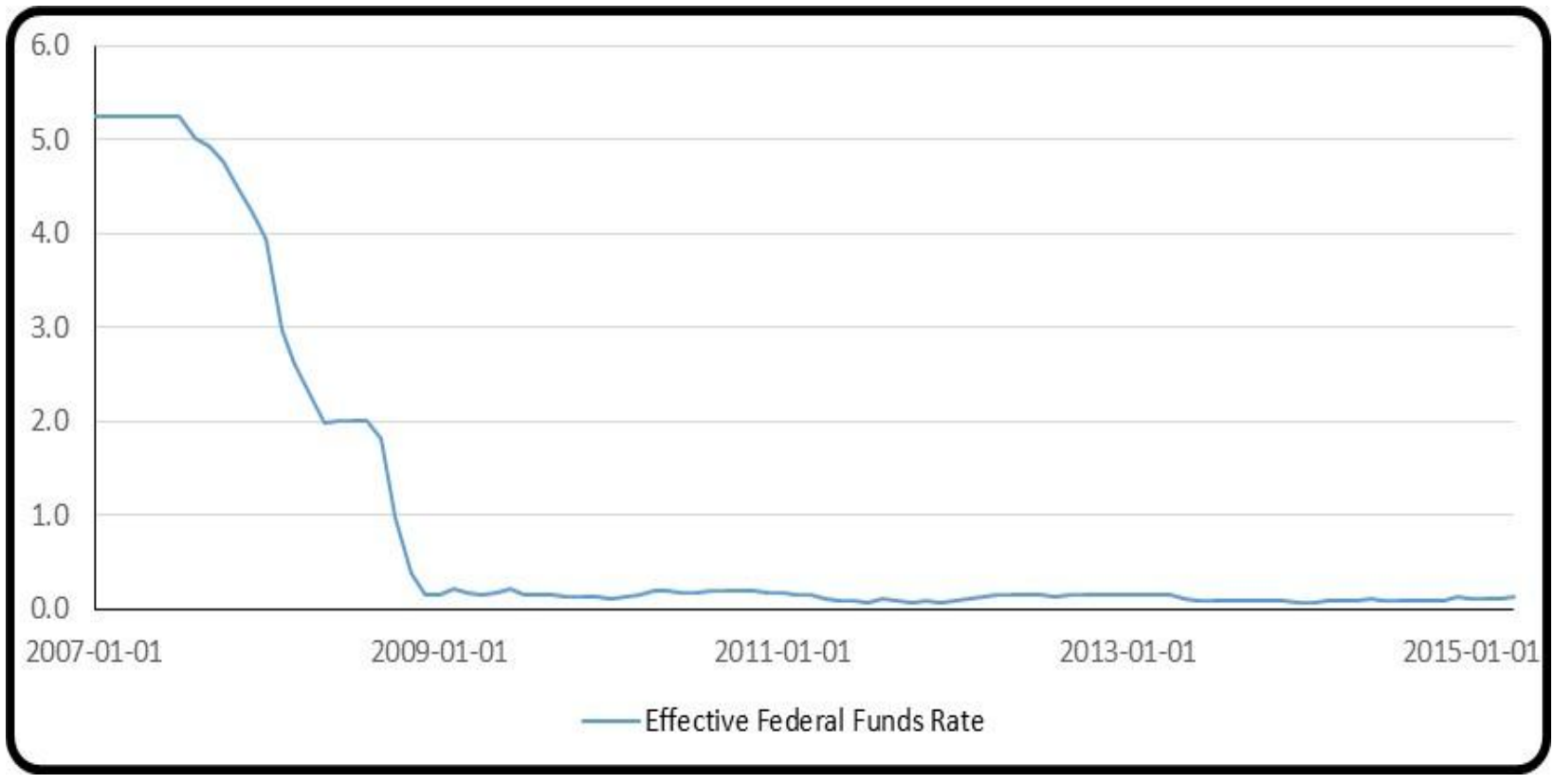

Source: Federal Reserve Bank of St. Louis

Figure 3. Effective Federal Funds Rate, Percent, Monthly, Not Seasonally Adjusted

\section{Quantitative Easing and Gross Domestic Product}

The economic crisis had a negative impact on US gross domestic product. The subprime mortgage crisis had a 
contagion effect on the economy so that gross domestic product suffered. As Figure 5 and Table 2 show, annual GDP based on 2009 chained dollars decreased by 0.3 percent in 2008 and, again, by 2.8 percent in 2009. After that, it recovered into positive territory but, remained at or below 2.5 percent between 2010 and 2014 .

A look at the quarterly GDP provides a detailed picture of the effect on GDP. According to the Bureau of Economic Analysis, quarterly GDP based on chained 2009 dollars had started to contract by the third quarter of 2008. It continued to contract till the second quarter of 2009 and, then, started registering positive growth. After that, it has registered mostly positive growth even though the growth rates have been quite low. Economic growth has been stronger in the last few quarters. While quarterly GDP started to grow after the second quarter of 2009, the growth rate was very uneven as shown in Figure 6. Quantitative easing has helped to boost the economy by increasing the money supply while maintaining the Federal Fund rate close to zero has allowed businesses to borrow cheaply and invest in their business operations. This helped to grow gross domestic product and recover the economy from its recessionary levels.

Also, quantitative easing accompanied with record low interest rates led to capital outflow from the US to emerging economies where capital could earn higher interest rates. The capital outflow depressed the exchange rate in favor of the US dollar. A depreciated US dollar would mean that US exports became cheaper in export destinations that would further lead to increases in demand for US exports. With higher demand for US exports, the export-oriented sectors in the US received a boost, leading to expansion in these sectors. Increased momentum in the export-oriented sectors helped to recover the GDP of the country.

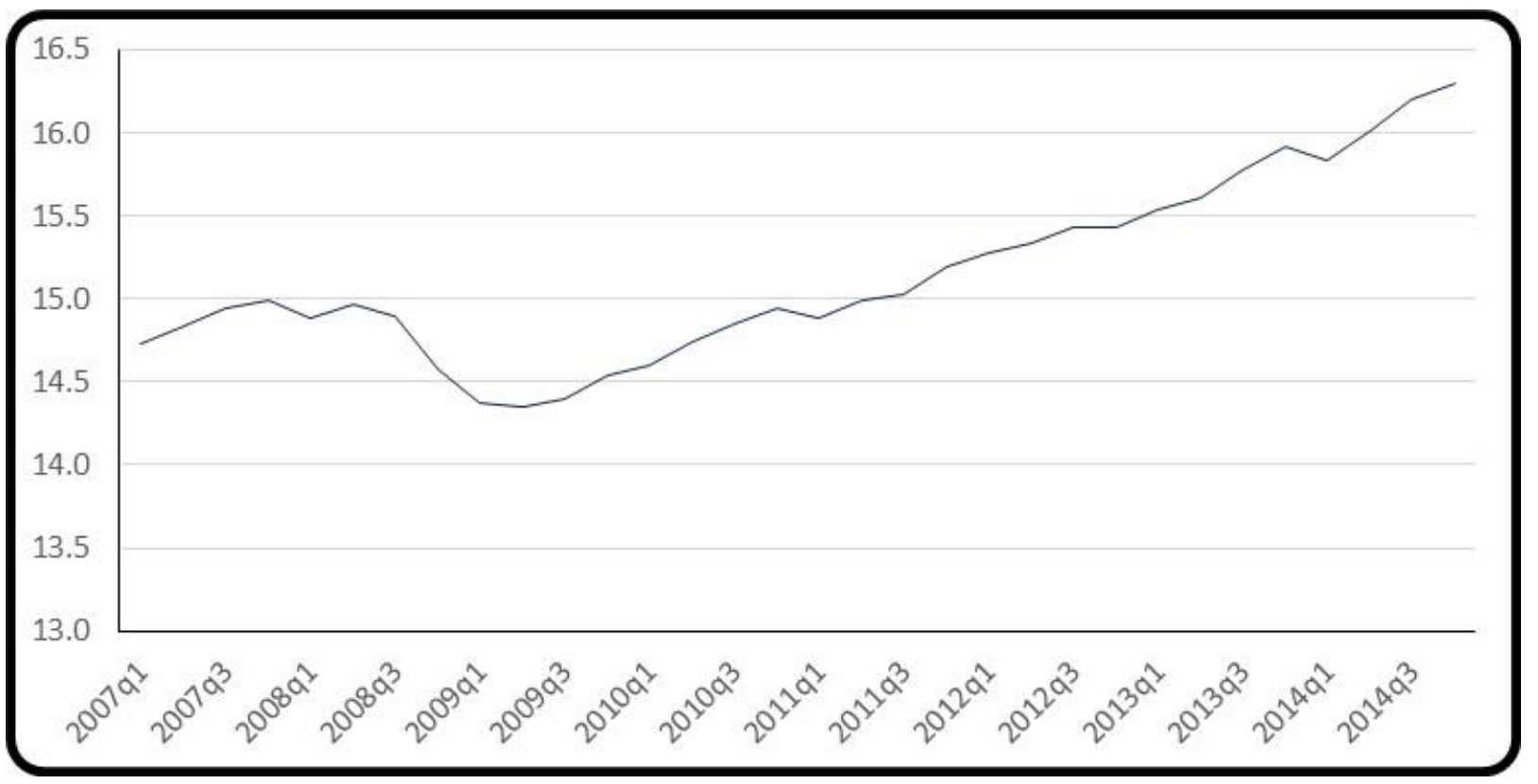

Source: Bureau of Economic Analysis

Figure 4. Quarterly GDP in trillions of chained 2009 dollars 


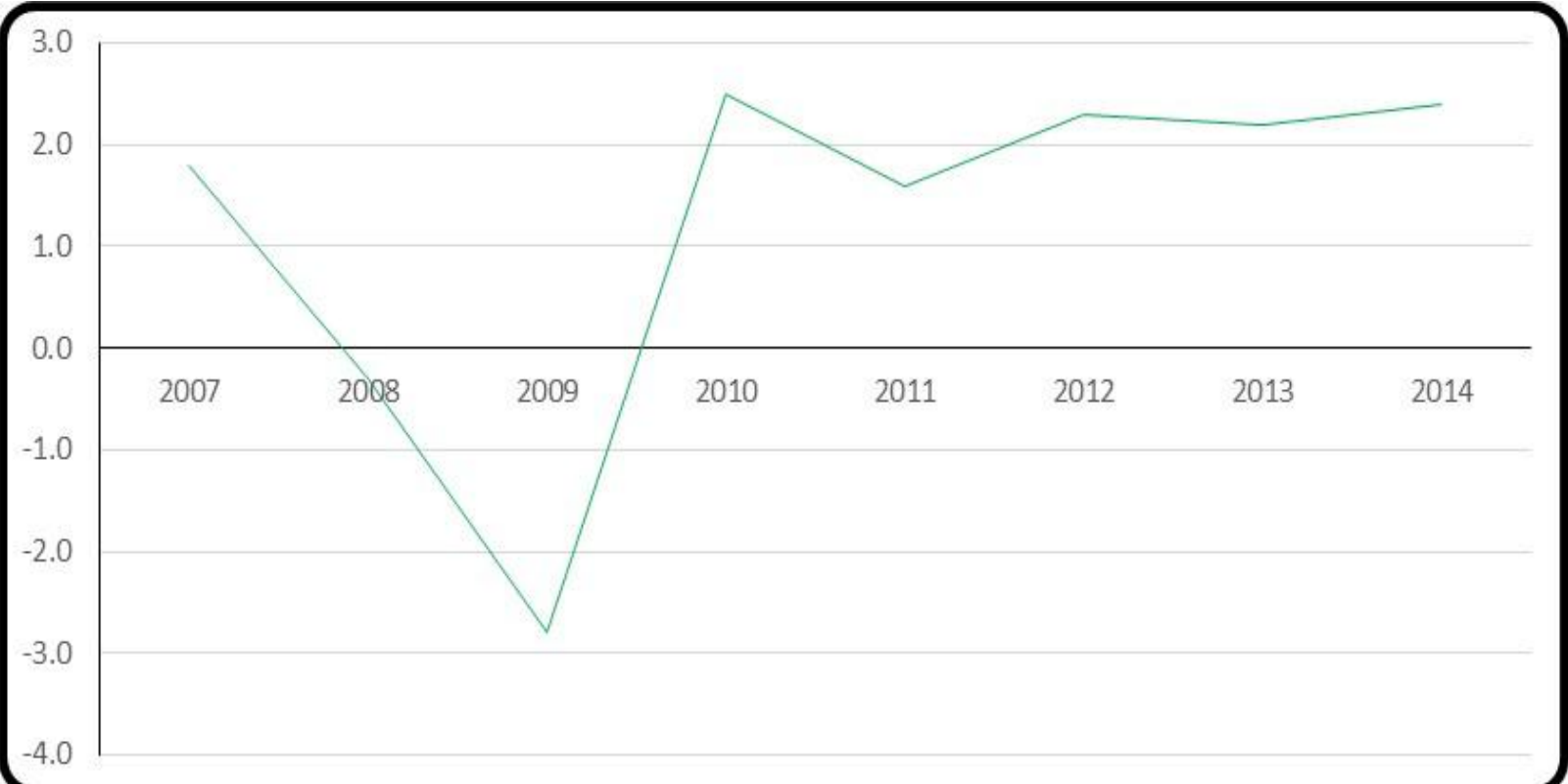

Source: Bureau of Economic Analysis

Figure 5. Annual GDP percent change based on chained 2009 dollars

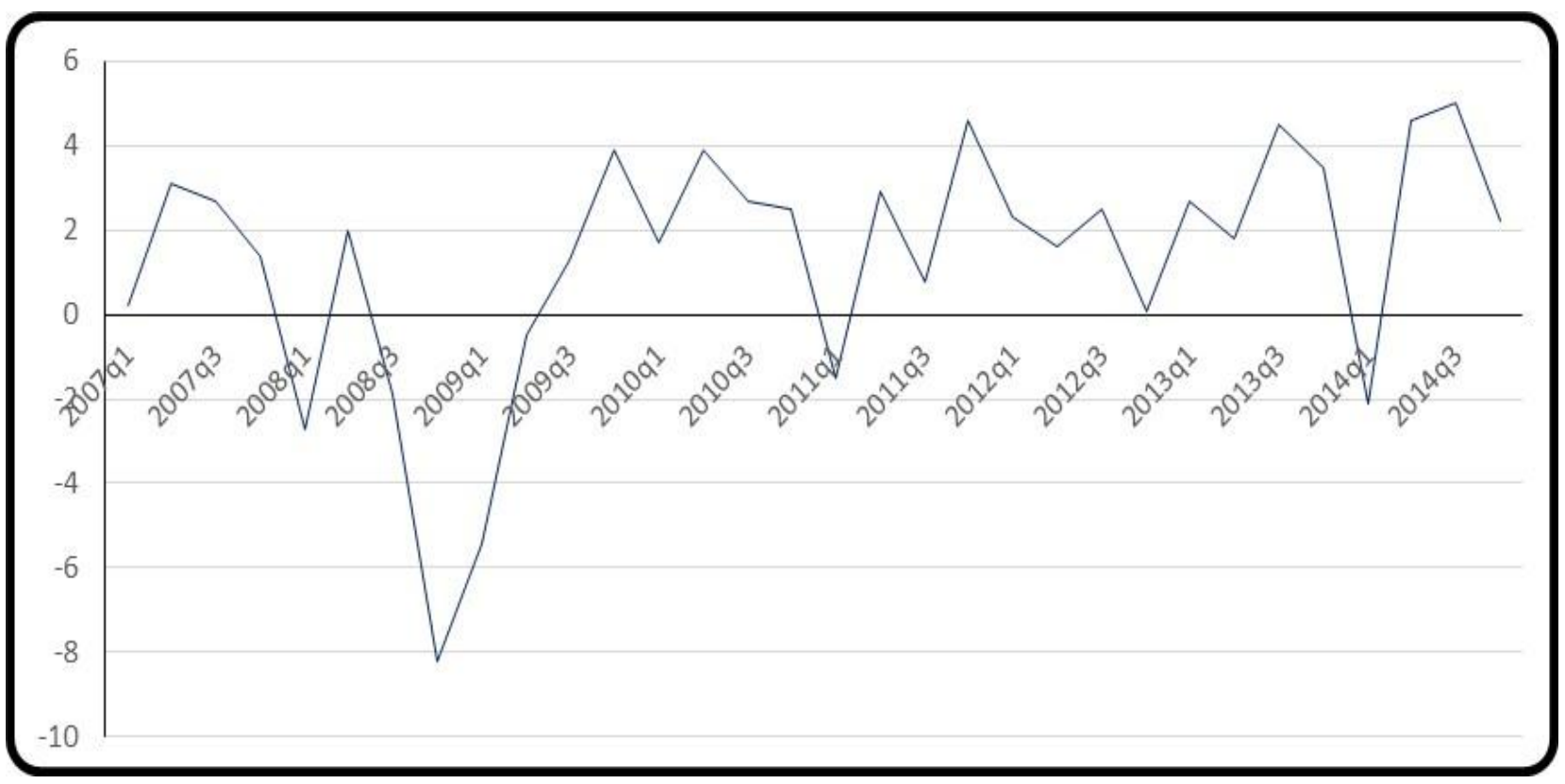

Source: Bureau of Economic Analysis

Figure 6. Quarterly GDP percent change based on chained 2009 dollars

Table 1. US Quarterly GDP in billions of dollars

\begin{tabular}{lcccc}
\hline Quarter & $\begin{array}{l}\text { Quarterly GDP in billions } \\
\text { of current dollars }\end{array}$ & $\begin{array}{l}\text { Percentage } \\
\text { Change (\%) }\end{array}$ & $\begin{array}{l}\text { Quarterly GDP in } \\
\text { billions of } \\
\text { 2009 dollars }\end{array}$ & $\begin{array}{l}\text { Percentage } \\
\text { chained }\end{array}$ \\
\hline $2007 \mathrm{q} 1$ & $14,233.2$ & 4.8 & $14,726.0$ & 0.2 \\
\hline
\end{tabular}




\begin{tabular}{|c|c|c|c|c|}
\hline $2007 q 2$ & $14,422.3$ & 5.4 & $14,838.7$ & 3.1 \\
\hline $2007 q 3$ & $14,569.7$ & 4.2 & $14,938.5$ & 2.7 \\
\hline $2007 q 4$ & $14,685.3$ & 3.2 & $14,991.8$ & 1.4 \\
\hline 2008q1 & $14,668.4$ & -0.5 & $14,889.5$ & -2.7 \\
\hline $2008 \mathrm{q} 2$ & $14,813.0$ & 4.0 & $14,963.4$ & 2.0 \\
\hline $2008 \mathrm{q} 3$ & $14,843.0$ & 0.8 & $14,891.6$ & -1.9 \\
\hline $2008 \mathrm{q} 4$ & $14,549.9$ & -7.7 & $14,577.0$ & -8.2 \\
\hline $2009 q 1$ & $14,383.9$ & -4.5 & $14,375.0$ & -5.4 \\
\hline $2009 q 2$ & $14,340.4$ & -1.2 & $14,355.6$ & -0.5 \\
\hline $2009 q 3$ & $14,384.1$ & 1.2 & $14,402.5$ & 1.3 \\
\hline $2009 q 4$ & $14,566.5$ & 5.2 & $14,541.9$ & 3.9 \\
\hline 2010q1 & $14,681.1$ & 3.2 & $14,604.8$ & 1.7 \\
\hline 2010q2 & $14,888.6$ & 5.8 & $14,745.9$ & 3.9 \\
\hline $2010 q 3$ & $15,057.7$ & 4.6 & $14,845.5$ & 2.7 \\
\hline $2010 q 4$ & $15,230.2$ & 4.7 & $14,939.0$ & 2.5 \\
\hline 2011q1 & $15,238.4$ & 0.2 & $14,881.3$ & -1.5 \\
\hline $2011 q 2$ & $15,460.9$ & 6.0 & $14,989.6$ & 2.9 \\
\hline $2011 \mathrm{q} 3$ & $15,587.1$ & 3.3 & $15,021.1$ & 0.8 \\
\hline $2011 q 4$ & $15,785.3$ & 5.2 & $15,190.3$ & 4.6 \\
\hline $2012 q 1$ & $15,956.5$ & 4.4 & $15,275.0$ & 2.3 \\
\hline $2012 q 2$ & $16,094.7$ & 3.5 & $15,336.7$ & 1.6 \\
\hline $2012 q 3$ & $16,268.9$ & 4.4 & $15,431.3$ & 2.5 \\
\hline $2012 q 4$ & $16,332.5$ & 1.6 & $15,433.7$ & 0.1 \\
\hline $2013 q 1$ & $16,502.4$ & 4.2 & $15,538.4$ & 2.7 \\
\hline $2013 q 2$ & $16,619.2$ & 2.9 & $15,606.6$ & 1.8 \\
\hline $2013 q 3$ & $16,872.3$ & 6.2 & $15,779.9$ & 4.5 \\
\hline $2013 q 4$ & $17,078.3$ & 5.0 & $15,916.2$ & 3.5 \\
\hline $2014 q 1$ & $17,044.0$ & -0.8 & $15,831.7$ & -2.1 \\
\hline $2014 q 2$ & $17,328.2$ & 6.8 & $16,010.4$ & 4.6 \\
\hline $2014 q 3$ & $17,599.8$ & 6.4 & $16,205.6$ & 5.0 \\
\hline $2014 q 4$ & $17,703.7$ & 2.4 & $16,294.7$ & 2.2 \\
\hline
\end{tabular}

Source: Bureau of Economic Analysis

Table 2. US Annual GDP in billions of chained 2009 dollars

\begin{tabular}{lcc}
\hline Year & $\begin{array}{r}\text { Annual GDP in billions of } \\
\text { chained 2009 dollars }\end{array}$ & $\begin{array}{r}\text { Annual GDP percent change } \\
\text { based on chained 2009 dollars }\end{array}$ \\
\hline 2007 & $14,873.7$ & 1.8 \\
2008 & $14,830.4$ & -0.3 \\
2009 & $14,418.7$ & -2.8 \\
2010 & $14,783.8$ & 2.5 \\
2011 & $15,020.6$ & 1.6 \\
2012 & $15,369.2$ & 2.3 \\
2013 & $15,710.3$ & 2.2 \\
2014 & $16,085.6$ & 2.4 \\
\hline
\end{tabular}

Source: Bureau of Economic Analysis 


\section{Quantitative Easing and Unemployment}

The economic crisis had a deleterious impact on unemployment. In the pre-crisis period, the unemployment rate was around five percent. However, the unemployment rate started to increase in the later part of 2008. It continued to increase and reached as high as ten percent in October 2009. The unemployment rate remained high for the successive years and went below seven percent in 2014. According to the Bureau of Labor Statistics, the unemployment rate was 5.6 percent in December 2014.

The unemployment numbers increased from around seven million before the recession to more than fifteen million in October 2009. After reaching this high level, unemployment started to decrease so that by April 2015, the level of unemployment was around 8.5 million. It seems that quantitative easing had a beneficial effect on unemployment. Millions of people were unemployed during the recession and quantitative easing generated momentum in the economy which helped to decrease the unemployment rate significantly from recessionary times.

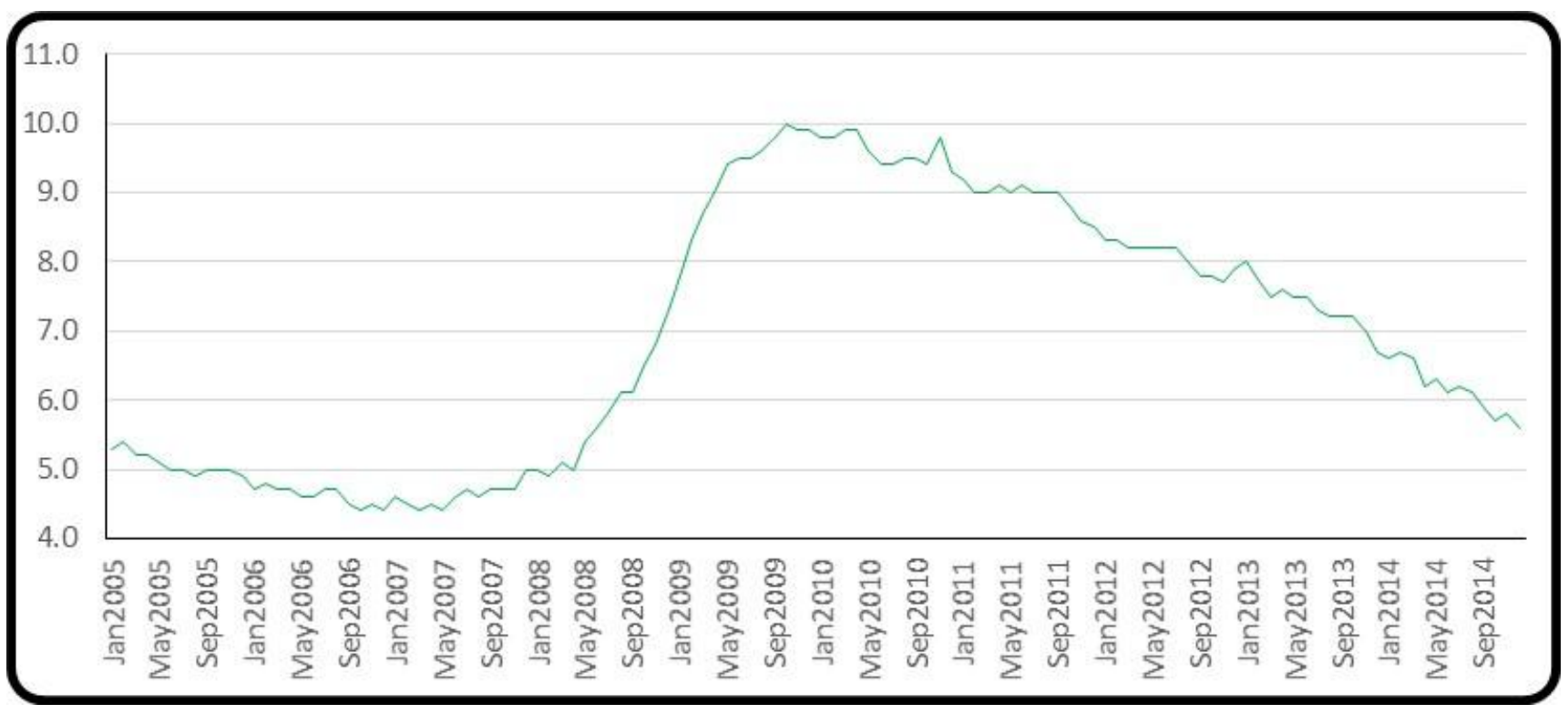

Source: Bureau of Labor Statistics

Figure 7. Unemployment Rate

Table 3. US Monthly Unemployment Rate

\begin{tabular}{ccccccccccccc}
\hline Year & Jan & Feb & Mar & Apr & May & Jun & Jul & Aug & Sep & Oct & Nov & Dec \\
\hline $\mathbf{2 0 0 5}$ & 5.3 & 5.4 & 5.2 & 5.2 & 5.1 & 5.0 & 5.0 & 4.9 & 5.0 & 5.0 & 5.0 & 4.9 \\
$\mathbf{2 0 0 6}$ & 4.7 & 4.8 & 4.7 & 4.7 & 4.6 & 4.6 & 4.7 & 4.7 & 4.5 & 4.4 & 4.5 & 4.4 \\
$\mathbf{2 0 0 7}$ & 4.6 & 4.5 & 4.4 & 4.5 & 4.4 & 4.6 & 4.7 & 4.6 & 4.7 & 4.7 & 4.7 & 5.0 \\
$\mathbf{2 0 0 8}$ & 5.0 & 4.9 & 5.1 & 5.0 & 5.4 & 5.6 & 5.8 & 6.1 & 6.1 & 6.5 & 6.8 & 7.3 \\
$\mathbf{2 0 0 9}$ & 7.8 & 8.3 & 8.7 & 9.0 & 9.4 & 9.5 & 9.5 & 9.6 & 9.8 & 10.0 & 9.9 & 9.9 \\
$\mathbf{2 0 1 0}$ & 9.8 & 9.8 & 9.9 & 9.9 & 9.6 & 9.4 & 9.4 & 9.5 & 9.5 & 9.4 & 9.8 & 9.3 \\
$\mathbf{2 0 1 1}$ & 9.2 & 9.0 & 9.0 & 9.1 & 9.0 & 9.1 & 9.0 & 9.0 & 9.0 & 8.8 & 8.6 & 8.5 \\
$\mathbf{2 0 1 2}$ & 8.3 & 8.3 & 8.2 & 8.2 & 8.2 & 8.2 & 8.2 & 8.0 & 7.8 & 7.8 & 7.7 & 7.9 \\
$\mathbf{2 0 1 3}$ & 8.0 & 7.7 & 7.5 & 7.6 & 7.5 & 7.5 & 7.3 & 7.2 & 7.2 & 7.2 & 7.0 & 6.7 \\
$\mathbf{2 0 1 4}$ & 6.6 & 6.7 & 6.6 & 6.2 & 6.3 & 6.1 & 6.2 & 6.1 & 5.9 & 5.7 & 5.8 & 5.6 \\
\hline
\end{tabular}

Source: Bureau of Labor Statistics 


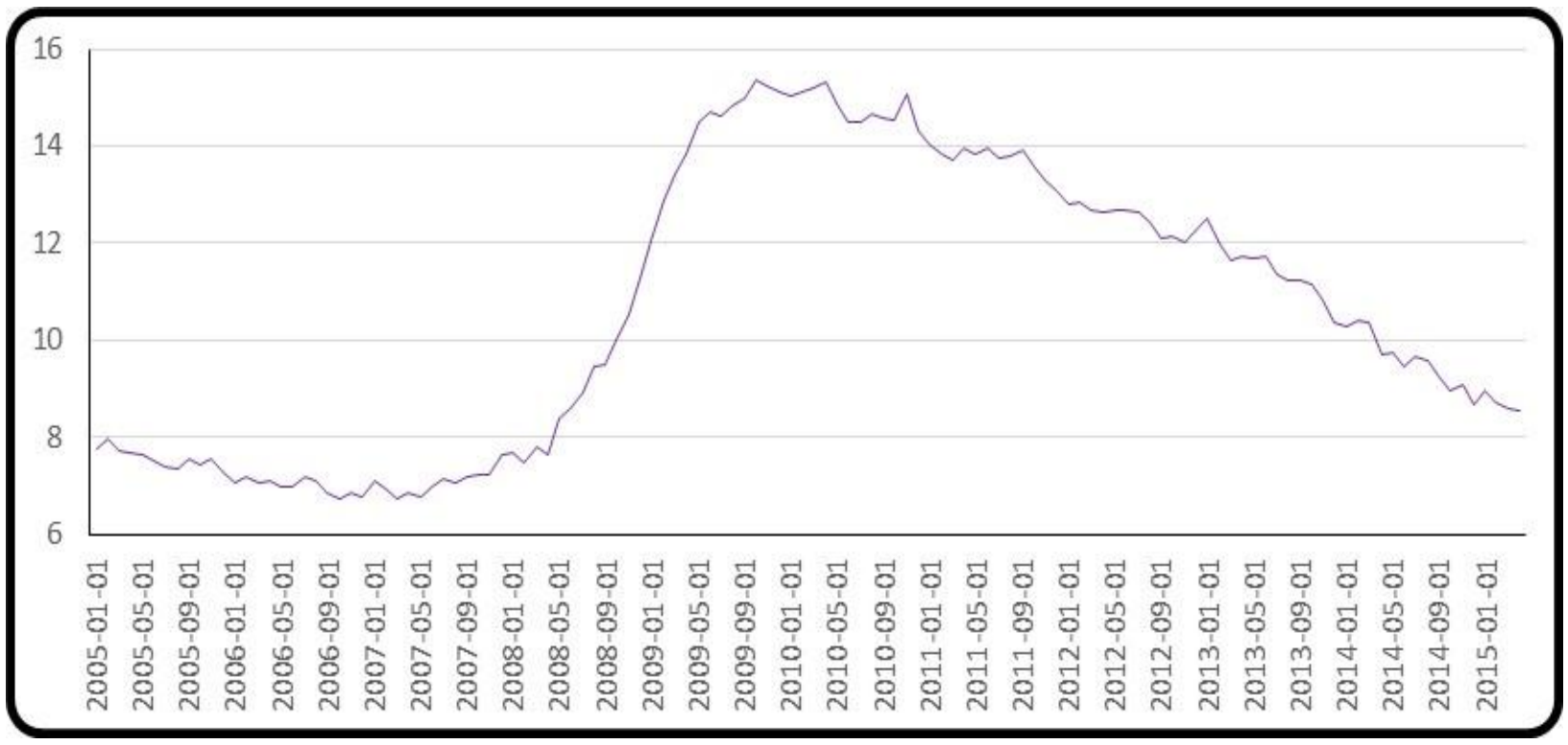

Source: Federal Reserve Bank of St. Louis

Figure 8. U.S. Unemployment (in Millions)

\section{Quantitative Easing and Inflation}

Quantitative easing led to an increase in the money supply in the US economy. Even though it was suggested that the expansionary money supply would lead to inflationary pressures in the economy, the inflation rate has remained relatively low since the introduction of quantitative easing. As Figure 9 and Table 4 show, inflation has remained mostly under three percent. An analysis of the trend of quarterly GDP in current and constant 2009 dollars also suggest that the inflation rate has been quite modest from when quantitative easing was started till now. One reason that the inflationary pressures were low is that capital offered low interest rate in the US while it offered higher interest rates in other countries, especially fast growing emerging economies. This led to capital outflow from the US economy to these emerging economies thereby, decreasing the inflationary pressures in the US economy. Even though inflation has remained at tolerable levels for the last several years, there is always a risk of higher inflation in the future brought about by significant infusion of capital in the economy.

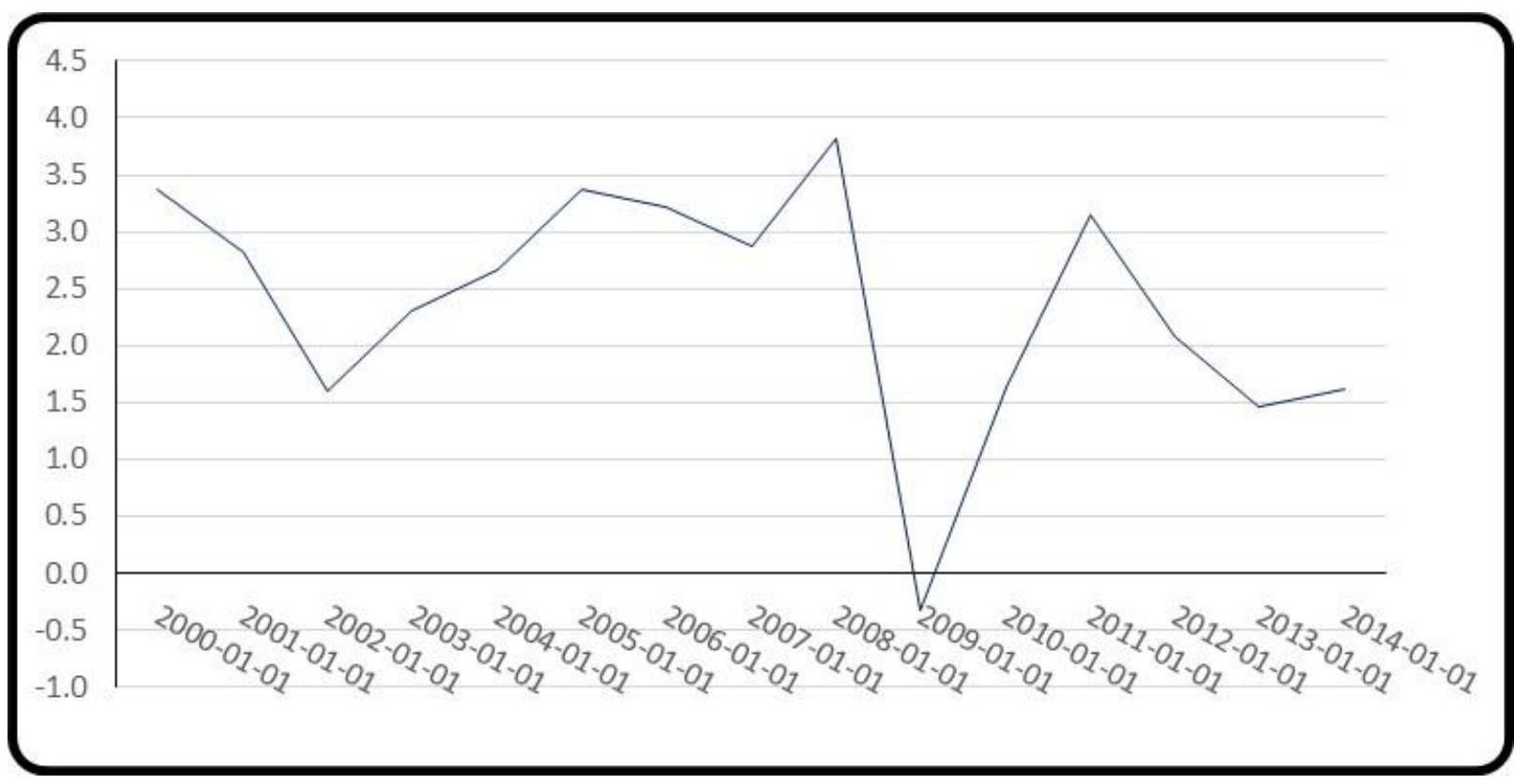

Source: Federal Reserve Bank of St. Louis, US. Bureau of Labor Statistics

Figure 9. Consumer Price Index for All Urban Consumers: All Items, Percent Change, Annual, Seasonally Adjusted 


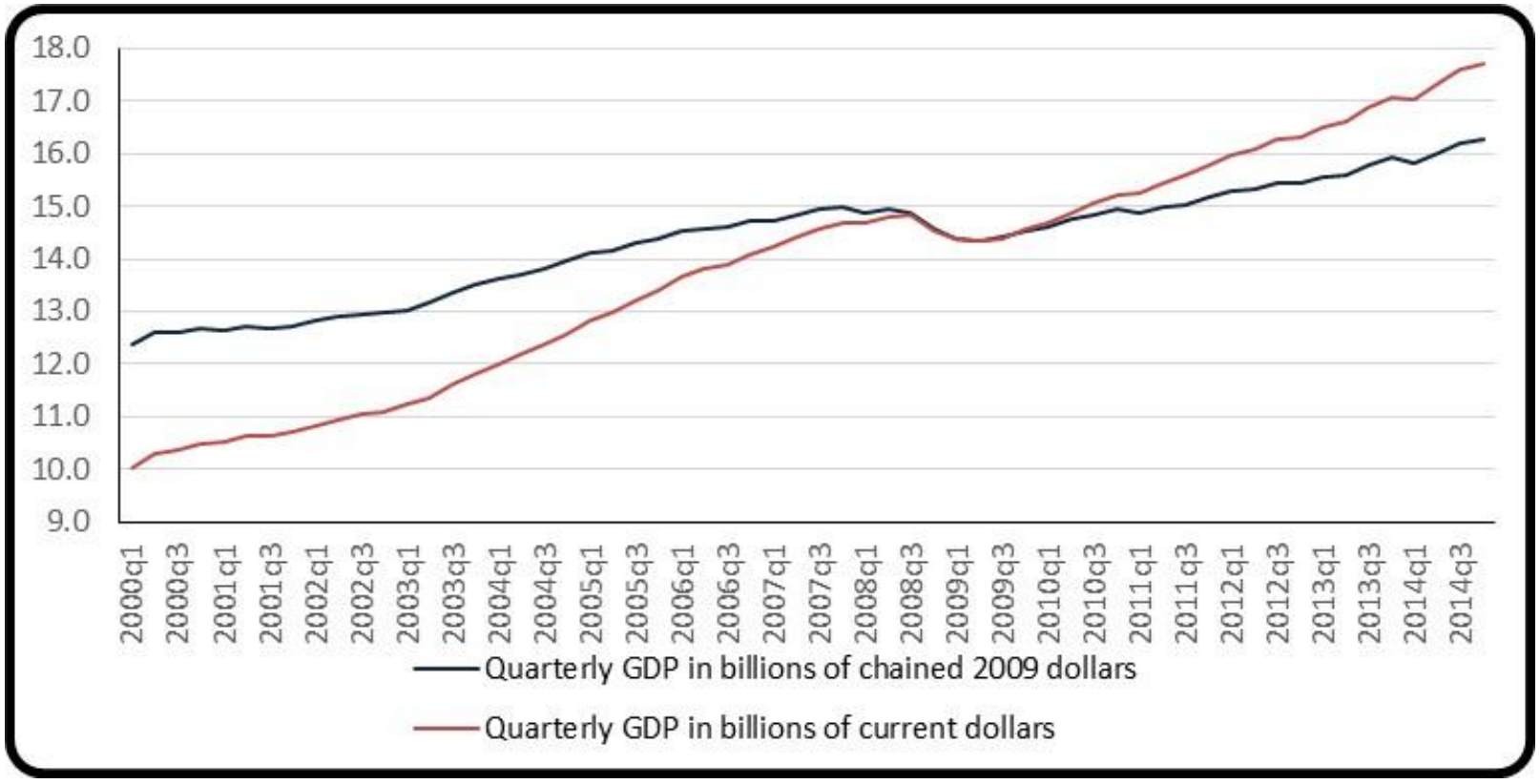

Source: Bureau of Economic Analysis

Figure 10. Quarterly GDP in trillions of current and chained 2009 dollars

Table 4. US Consumer Price Index for All Urban Consumers: All Items, Percent Change, Annual, Seasonally Adjusted

\begin{tabular}{lc}
\hline Observation Date & Consumer Price Index for All Urban Consumers, Percent Change \\
\hline $2000-01-01$ & 3.4 \\
$2001-01-01$ & 2.8 \\
$2002-01-01$ & 1.6 \\
$2003-01-01$ & 2.3 \\
$2004-01-01$ & 2.7 \\
$2005-01-01$ & 3.4 \\
$2006-01-01$ & 3.2 \\
$2007-01-01$ & 2.9 \\
$2008-01-01$ & 3.8 \\
$2009-01-01$ & -0.3 \\
$2010-01-01$ & 1.6 \\
$2011-01-01$ & 3.1 \\
$2012-01-01$ & 2.1 \\
$2013-01-01$ & 1.5 \\
$2014-01-01$ & 1.6 \\
\hline
\end{tabular}

Source: Federal Reserve Bank of St. Louis

\section{Quantitative Easing and Debt}

Quantitative easing was accompanied by an increase in gross federal debt. As shown in Figure 11, gross federal debt increased from US \$9.9 trillion in September 2008 to US \$17.8 trillion in September 2014. The bailout of financial institutions like American International Group (AIG), Fannie Mae and Freddie Mac led to increase in the federal debt. During this time, gross federal debt held by the public more than doubled while that held by foreigners and international investors increased by a lesser amount demonstrating that most of gross federal debt was actually held by US citizens. During the 2008 to 2014 period, gross federal debt held by the public as percent of GDP increased substantially from 39.4 percent to 73.4 percent indicating that the public held most of the increase in gross federal debt. 
Increased government expenditure during the economic crisis led to increase in gross federal debt. As a percent of gross domestic product, gross federal debt increased from 67.8 percent in the beginning of 2008 to 102.2 percent in the beginning of 2014. The holding of gross federal debt more than the GDP may not be healthy for the economy while putting significant debt burden on future generations. The response of the US government to the economic crisis by increasing government expenditures including bailing out financial institutions led to a rise in gross federal debt.

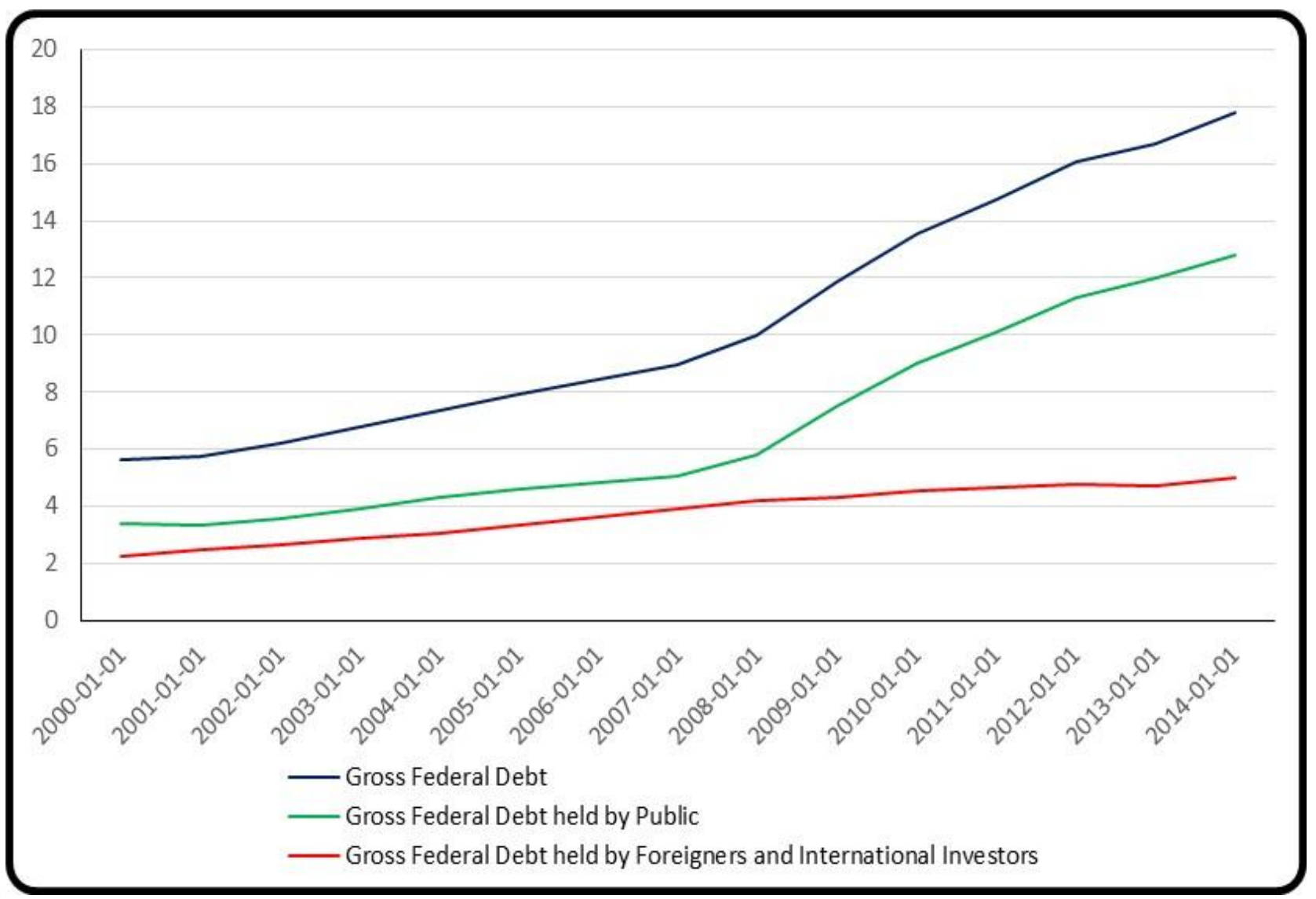

Source: Federal Reserve Bank of St. Louis

Figure 11. Gross Federal Debt, Trillions of Dollars, Annual, Not Seasonally Adjusted 


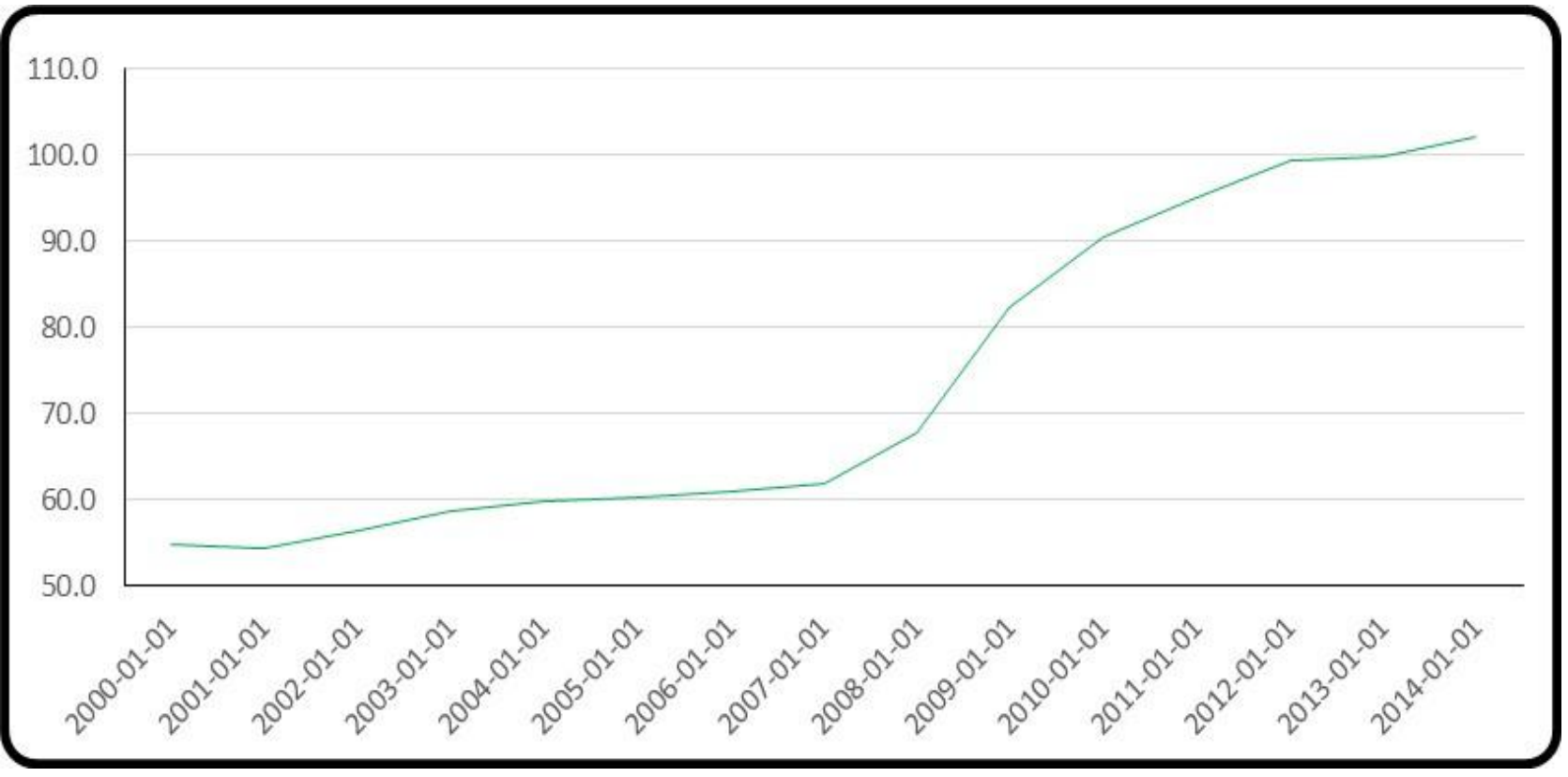

Source: Federal Reserve Bank of St. Louis

Figure 12. Gross Federal Debt as Percent of Gross Domestic Product, Annual, Not Seasonally Adjusted

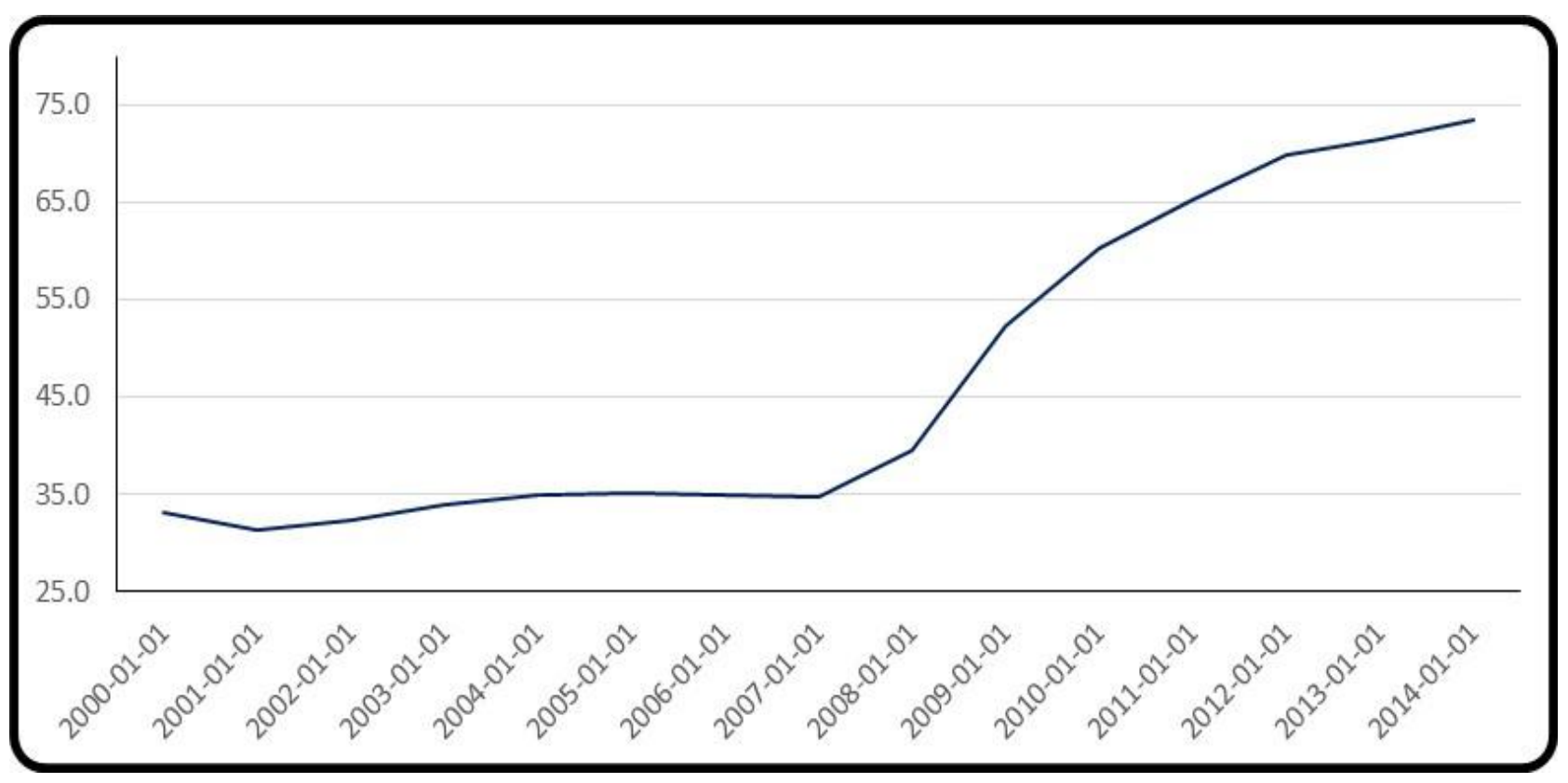

Source: Federal Reserve Bank of St. Louis

Figure 13. Gross Federal Debt Held by the Public as Percent of Gross Domestic Product, Annual, Not Seasonally Adjusted 
Table 5. Gross Federal Debt, Billions of Dollars, Annual, Not Seasonally Adjusted

\begin{tabular}{lrrr}
\hline $\begin{array}{l}\text { Observation } \\
\text { Date }\end{array}$ & $\begin{array}{r}\text { Gross Federal } \\
\text { Debt }\end{array}$ & $\begin{array}{r}\text { Gross Federal Debt held } \\
\text { by Public }\end{array}$ & $\begin{array}{r}\text { Gross Federal Debt held by Foreigners and } \\
\text { International Investors* }\end{array}$ \\
\hline $2000-09-30$ & 5628.7 & 3409.8 & 2218.9 \\
$2001-09-30$ & 5769.9 & 3319.6 & 2450.3 \\
$2002-09-30$ & 6198.4 & 3540.4 & 2658.0 \\
$2003-09-30$ & 6760.0 & 3913.4 & 2846.6 \\
$2004-09-30$ & 7354.7 & 4295.5 & 3059.2 \\
$2005-09-30$ & 7905.3 & 4592.2 & 3313.1 \\
$2006-09-30$ & 8451.4 & 4829 & 3622.4 \\
$2007-09-30$ & 8950.7 & 5035.1 & 3915.6 \\
$2008-09-30$ & 9986.1 & 5803.1 & 4183.0 \\
$2009-09-30$ & 11875.9 & 7544.7 & 4331.2 \\
$2010-09-30$ & 13528.8 & 9018.9 & 4509.9 \\
$2011-09-30$ & 14764.2 & 10128.2 & 4636.0 \\
$2012-09-30$ & 16050.9 & 11281.1 & 4769.8 \\
$2013-09-30$ & 16719.4 & 11982.7 & 4736.7 \\
$2014-09-30$ & 17794.5 & 12779.9 & 5014.6 \\
\hline
\end{tabular}

Source: Federal Reserve Bank of St. Louis

*Author's Calculation

Table 6. Gross Federal Debt as Percent of GDP, Annual, Not Seasonally Adjusted

\begin{tabular}{lcc}
\hline Observation Date & Gross Federal Debt as Percent of GDP & Gross Federal Debt Held by the Public as Percent of GDP \\
\hline $2000-01-01$ & 54.7 & 33.2 \\
$2001-01-01$ & 54.3 & 31.3 \\
$2002-01-01$ & 56.5 & 32.3 \\
$2003-01-01$ & 58.7 & 34.0 \\
$2004-01-01$ & 59.9 & 35.0 \\
$2005-01-01$ & 60.4 & 35.1 \\
$2006-01-01$ & 61.0 & 34.9 \\
$2007-01-01$ & 61.8 & 34.8 \\
$2008-01-01$ & 67.8 & 39.4 \\
$2009-01-01$ & 82.4 & 52.3 \\
$2010-01-01$ & 90.4 & 60.3 \\
$2011-01-01$ & 95.1 & 65.3 \\
$2012-01-01$ & 99.3 & 69.8 \\
$2013-01-01$ & 99.7 & 71.5 \\
$2014-01-01$ & 102.2 & 73.4 \\
\hline
\end{tabular}

Source: Federal Reserve Bank of St. Louis

\section{Quantitative Easing and Asset Prices}

With the advent of the economic crisis, the prices of securities were affected. The S\&P 500 index went down with the emergence of the economic crisis. It went below the 700 mark which showed the adverse impact that the economic crisis had on the stock market. When quantitative easing was introduced, there was availability of cheap capital in the market and some of it was invested in the stock market. This led to the rejuvenation of the stock market. The S\&P 500 index consistently increased due to the inflow of capital in the stock market leading to an appreciation in the prices of stocks. The S\&P 500 index has surpassed the 2000 mark by April 2015. 


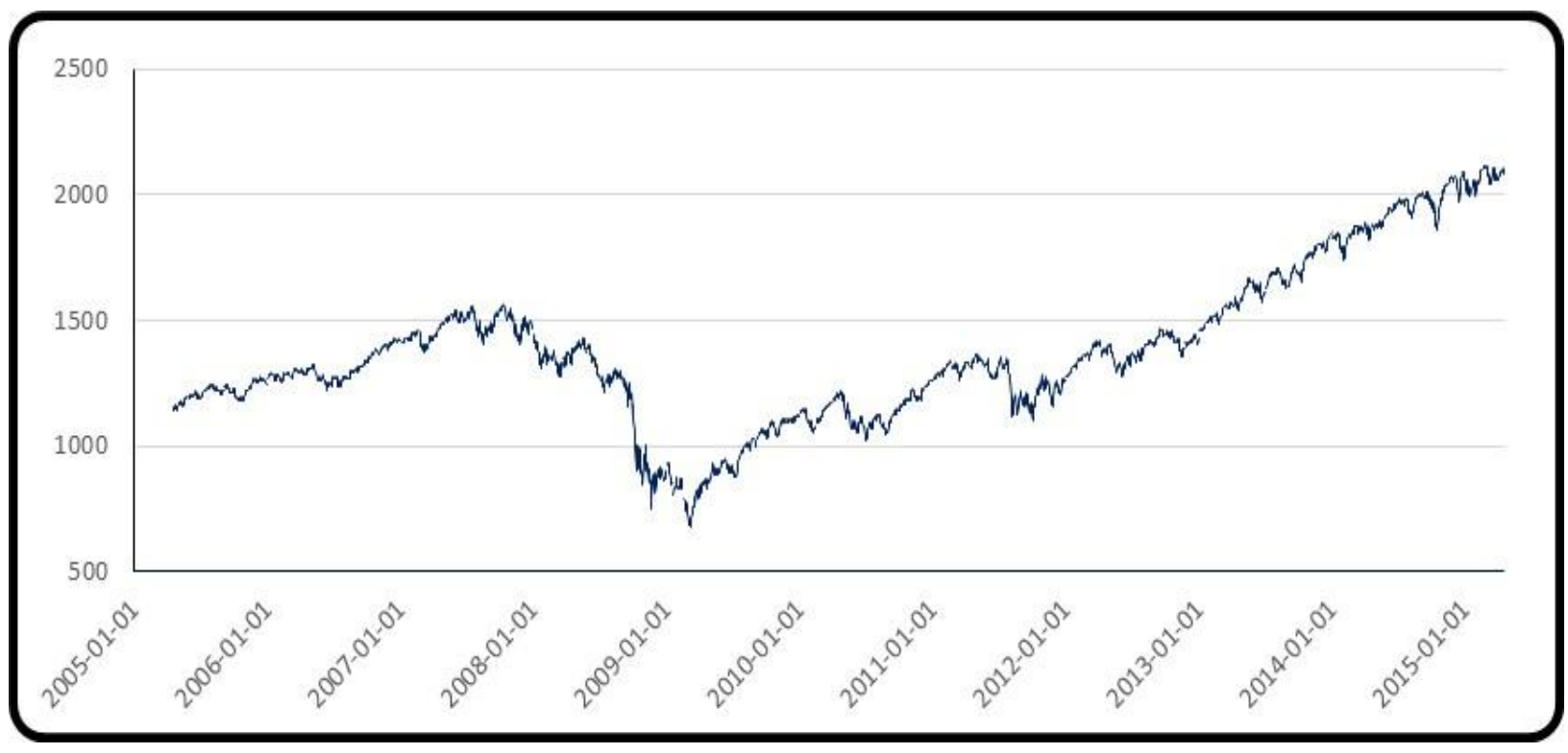

Source: S\&P Dow Jones Indices LLC

Figure 14. S\&P Index

Quantitative easing has had a positive impact on the stock market. The availability of cheap capital led to increased investment in stocks which fueled the increase in the prices of stocks. The stock market has recovered from its recessionary levels.

\section{Experience of other countries}

Quantitative easing has been used in other countries, besides the US. It is currently being implemented in the European Union as well as Japan.

\subsection{Quantitative Easing in Japan in early 2000}

In the beginning of the 1990s, Japan experienced a collapse in its asset prices. This led to low economic growth and deflation in the Japanese economy. The Bank of Japan maintained close to zero interest rates since 1999 to bolster the economy. In addition, it adopted quantitative easing in March 2001. The central bank started buying asset-backed securities and equities, long-term Japanese government bonds and extended the terms of its commercial paper-purchasing operations. As a result of quantitative easing, BOJ's commercial bank current account balance increased from $¥ 5$ trillion to $¥ 35$ trillion. The quantitative easing ended in March 2006.

Even though quantitative easing helped in stabilizing the financial system in the Japanese economy, it did not have significant positive effect on the economy. GDP of the Japanese economy fell, real wages decreased and price levels were stagnant. It led to the creation of zombie banks, insolvent lenders propped up by cheap cash. These zombie banks in turn were lending to zombie firms, large firms that were unprofitable but were kept from becoming bankrupt. The companies had substantial debt and the government sustained high levels of debt. It has been argued by Schuman (2008) that the Japanese economy did not start to recover until the practice of propping up zombie banks and firms ended. Spiegel (2006) states that, "Moreover, in strengthening the performance of the weakest Japanese banks, quantitative easing may have had the undesired impact of delaying structural reform."

\subsection{Quantitative Easing in the UK}

The Bank of England introduced quantitative easing to counter the onslaught of the economic crisis. It decreased the Bank rate on commercial bank reserves to 0.5 percent and purchased $£ 375$ billion of financial assets, mostly UK government securities, gilts. It lead to an increase in financial asset prices. According to the Bank of England (2012), quantitative easing of $£ 200$ billion between March 2009 and January 2010 is predicted to have increased the level of real GDP by 1.5 to 2.0 percent.

\subsection{Quantitative Easing in the European Union}

The European Central Bank (ECB) had also initiated quantitative easing of purchasing $€ 60$ billion of financial assets every month. This is to rejuvenate the European economy and increase the level of inflation. The program is expected to continue till September 2016 and would purchase more than $€ 1$ trillion of financial assets. The financial assets bought by ECB include government bonds, debt-securities issued by European institutions and private-sector bonds. 


\subsection{Recent Quantitative Easing in Japan}

In April 2013, the Bank of Japan started a significant quantitative easing program worth $\$ 1.4$ trillion. Experiencing a low inflation rate and dampened consumer spending, Japan expanded its government bonds purchasing program to $¥ 80$ trillion a year from the previous level of $¥ 60-70$ trillion a year. Named Abenomics after Japan’s Prime Minister Shinzo Abe, the policy targets an inflation rate of 2 percent while boosting economic growth and exports.

\section{Will Quantitative Easing Lead to Economic Crisis in the Future?}

Quantitative easing has led to certain situations. It has influenced income inequality and stock prices. These effects may lead to certain problems in the future.

\subsection{Increased Income Inequality}

The expansionary monetary policy led to increased investment in financial assets. As high-income individuals tend to invest more in financial assets and also have more financial capability to invest in the stock market, quantitative easing may have led to a situation where high-income individuals could avail cheap finance and invest more in the stock market. As the prices of financial assets increased, this led to higher wealth of high-income individuals and may have contributed to increased income inequality in the country. Watkins (2014) demonstrates that quantitative easing has primarily benefited people in the high income brackets. Also, he asks about the fairness of quantitative easing as it seems to benefit high-income individuals.

Quantitative easing has led to increased income inequality which may lead to economic and non-economic problems. As income inequality is socially unpopular, it could lead to discontent among the low income groups. Also, there have been arguments that increased income inequality may lead to lower economic growth. From being considered unfair as it benefits high-income individuals, quantitative easing has contributed to higher income inequality in the US.

\subsection{Inflated Asset Prices}

Quantitative easing had an impact on financial assets. The supply of cheap capital flowed into the stock market and were invested in various kinds of financial assets. This led to an increase in prices of financial assets. As Figure 14 shows, the S\&P index sharply decreased during the economic crisis. With the introduction of quantitative easing, the S\&P index started to recover. It increased consistently as quantitative easing continued. By early 2015 , the S\&P index has crossed the 2000 mark. Figure 14 demonstrates the significant increase in the S\&P index in the last several years. The S\&P index has crossed the level before the commencement of the economic crisis. The sharp increase in the S\&P index shows that asset prices have increased significantly. It may be argued that quantitative easing contributed to inflated asset prices. This may lead to the creation of asset bubbles. The creation of asset bubbles would be harmful for the US economy; once the bubble bursts, it could lead to serious instability in the economy that could reduce economic growth and increase unemployment levels. Again, as high-income individuals mostly invest in the stock market, their investments financed by the availability of cheap capital could lead to asset bubbles, creating the potential of economic instability in the future. Therefore, continued increase in the prices of financial assets that could lead to the creation of asset bubbles need to be effectively handled so that it does not lead to future disruption in the economy.

The Federal Reserve has maintained record low interest rates. Once it starts raising the interest rate, capital may flow into the US from other countries, especially the emerging economies, attracted by higher interest rates. Also, as the US economy grows stronger relative to other countries, including emerging economies, it would increasingly attract capital inflow into the US as a stronger economy would signal more opportunities for capital investment as well as higher returns to investment. The inflow of capital into the US could lead to further increase in financial asset prices, real estate prices, etc. Further boost in stock prices could lead to the creation of asset bubbles and pave the way for potential financial instability and economic crisis.

\section{Is Quantitative Easing Sufficient?}

Quantitative easing led to significant improvements in the economy like increase in GDP growth and decrease in the unemployment level. However, quantitative easing by itself may not be sufficient for lasting changes and improvements in the economy. Structural changes are required to make a long-lasting impact on the economy. Regulations like the Dodd-Frank Wall Street Reform and Consumer Protection Act, and Volcker Rule are appropriate measures implemented by the US government to stop the recurrence of economic crisis. The reintroduction of the Glass-Steagall Act that separated commercial banking and investment banking could make the financial system healthier. In turn, a healthy financial system would lead to a better economy that is less prone to financial crisis.

Regulations in lending practices, including limitations in financial engineering, would be considered appropriate. Also, the practice of making financial instruments less opaque so that investors are well-aware of the risks and challenges of investing in financial assets would be prudent. Again, change in the "too big to fail" policy is wise; then, the financial 
institutions are efficient and manageable in size so that the bankruptcy and collapse of one institution does not have serious consequences for the economy. Furthermore, regulations that limit financial institutions from taking too much risk are sagacious while limitations and supervision of "shadow banking" are important. Also, the practice of private profits and social losses need to be curtailed to mitigate the risks of economic crisis. Therefore, quantitative easing combined with regulations and structural changes in the economy are needed to have long-lasting impact on the US economy, which would reduce the risks of further economic crisis.

\section{Conclusion}

Quantitative easing has had positive impact on the US economy. Gross domestic product has substantially improved while the unemployment level has decreased significantly and is continuing to decrease as the economy grows. Also, inflation has been maintained at a manageable level till now. The authorities have to be aware that the expansionary monetary policy does not lead to higher inflation in the future. On the negative side, US Gross Federal Debt has increased considerably.

By itself, quantitative easing may not be sufficient for bringing stable and lasting beneficial effects to the economy. Additional changes need to be undertaken to make quantitative easing effective in the long run. Structural changes need to be made in the economy to make the beneficial effects of quantitative easing permanent. Changes like the "too big to fail" policy would make the economy less vulnerable to economic crisis in the future. Again, regulations like the Dodd-Frank Wall Street Reform and Consumer Protection Act, and Volcker Rule are necessary to mitigate the risks of economic crisis. Also, the reintroduction of the Glass-Steagall Act would help to make the financial system more stable and reduce the risks of potential economic crisis.

\section{References}

Allen, K. (2015). Quantitative easing around the world: lessons from Japan, UK and US. The Guardian, January 22. http://www.theguardian.com/business/2015/jan/22/quantitative-easing-around-the-world-lessons-from-japan-uk-an d-us.

Bank of England. (2012). The Distributional Effects of Asset Purchases. Bank of England News Release, July. http://www.bankofengland.co.uk/publications/Documents/news/2012/nr073.pdf.

BBC News Business. (2015). What is quantitative easing? BBC News, January 22. http://www.bbc.com/news/business-15198789.

BBC News Business. (2011). Japan government and central bank intervene to cut yen. BBC News, August 4. http://www.bbc.com/news/business-14398392.

Benford, James, Stuart Berry, Kalin Nikolov and Chris Young. (2009). Quantitative Easing. Bank of England Quarterly Bulletin 2009 Q2, June. 90-100.

http://www.bankofengland.co.uk/publications/Documents/quarterlybulletin/qb090201.pdf.

Bernanke, B. (2009). The Crisis and the Policy Response. Board of Governors of the Federal Reserve System 2009 Speeches, January 13. http://www.federalreserve.gov/newsevents/speech/bernanke20090113a.htm.

Bernanke, B., \& Mark, G. (2000). Monetary Policy and Asset Price Volatility. NBER Working Paper 7559, February. http://www.nber.org/papers/w7559.

Bird, M. (2014). A beginner's guide to quantitative easing. World Economic Forum, https://agenda.weforum.org/2014/11/a-beginners-guide-to-quantitative-easing.

Blackstone, B., Paul, H., \& Marcus, W. (2015). Aggressive ECB Stimulus Ushers in New Era for Europe. The Wall Street Journal, January 22. http://www.wsj.com/articles/ecb-announces-stimulus-plan-1421931011.

Breedon, F., Jagjit, S. C., \& Alex, W. (2012). The Financial Market Impact of UK Quantitative Easing. BIS Papers No. 65, May. 277-304. http://www.bis.org/publ/bppdf/bispap65p_rh.pdf.

Bunker, N. (2015). What caused the US housing bubble? World Economic Forum, May 29. https://agenda.weforum.org/2015/05/what-caused-the-us-housing-bubble.

Cho, D., \& Changyong, R. (2013). Effects of Quantitative Easing on Asia: Capital Flows and Financial Markets. ADB Economics Working Paper Series 350, June. http://www.adb.org/sites/default/files/publication/30283/ewp-350.pdf.

Claeys, G. (2015). What's Driving Expectations of Rising Inflation? World Economic Forum, April 22. https://agenda.weforum.org/2015/04/whats-driving-expectations-of-rising-inflation.

Denning, S. (2011). Lest We Forget: Why We Had a Financial Crisis. Forbes, November 22. http://www.forbes.com/sites/stevedenning/2011/11/22/5086.

European Central Bank. (2015). ECB announces expanded asset purchase programme. European Central Bank Press 
Release, January 22. https://www.ecb.europa.eu/press/pr/date/2015/html/pr150122_1.en.html.

Fawley, B. W., \& Christopher, J. N. (2013). Four Stories of Quantitative Easing. Federal Reserve Bank of St. Louis Review, January/February. 95(1). 51-88. https://research.stlouisfed.org/publications/review/13/01/Fawley.pdf.

Feldstein, M. (2015). What's causing America's low inflation? World Economic Forum, May 29. https://agenda.weforum.org/2015/05/whats-causing-americas-low-inflation.

Fratzscher, M., Marco-Lo D., \& Roland, S. (2013). On the International Spillovers of US Quantitative Easing. European Central Bank Working Paper Series 1557, June. https://www.ecb.europa.eu/pub/pdf/scpwps/ecbwp1557.pdf.

Gasper, V. (2015). How can we better manage economic risks? World Economic Forum, March 19. https://agenda.weforum.org/2015/03/how-can-we-better-manage-economic-risks.

Hurd, M. D., \& Susan, R. (2010). Effects of the Financial Crisis and Great Recession on American Households. NBER Working Paper 16407, September. http://www.nber.org/papers/w16407.

Insana, R. (2015). The really scary thing about Europe's QE plan. CNBC, January 28. http://www.cnbc.com/id/102376195.

International Monetary Fund. (2014). Shadow Banking around the Globe: How Large, and How Risky? Chapter 2 from Global Financial Stability Report, IMF. October. http://www.imf.org/external/pubs/ft/gfsr/2014/02/index.htm.

Irwin, N. (2014). Quantitative Easing is Ending. Here's what it did, in Charts. New York Times. October 29. http://www.nytimes.com/2014/10/30/upshot/quantitative-easing-is-about-to-end-heres-what-it-did-in-seven-charts. html.

Joyce, M. A. S., Ana, L., Ibrahim, S., \& Matthew, T. (2011). The Financial Market Impact of Quantitative Easing in the United Kingdom, International Journal of Central Banking, 7(3), 113-161. http://www.ijcb.org/journal/ijcb11q3a5.pdf.

Joyce, Michael, David Miles, Andrew Scott and Dimitri Vayanos. (2012). Quantitative Easing and Unconventional Monetary Policy-An Introduction. The Economic Journal. 122 (November). F271-F288. http://onlinelibrary.wiley.com/doi/10.1111/j.1468-0297.2012.02551.x/pdf.

Joyce, Michael, Matthew Tong \& Robert Woods. (2011). The United Kingdom's quantitative easing Policy: design, operation and impact. Bank of England Quarterly Bulletin Q3, 200-212. http://www.bankofengland.co.uk/publications/Documents/quarterlybulletin/qb110301.pdf.

Kapetanios, G., Haroon, M., Ibrahim, S., \& Konstantinos, T. (2012). Assessing the economy-wide effects of quantitative easing. Bank of England Working Paper, 443,

http://www.bankofengland.co.uk/research/Documents/workingpapers/2012/wp443.pdf.

Krishnamurthy, Arvind and Annette Vissing-Jorgensen (2011). The Effects of Quantitative Easing on Interest Rates: Channels and Implications for Policy. NBER Working Paper 17555, October. http://www.nber.org/papers/w17555.

Kynge, James. (2014). Fed leaves emerging markets exposed. Financial Times, October 29. http://www.ft.com/intl/cms/s/0/eee96c0e-5f8a-11e4-8c27-00144feabdc0.html\#axzz3c8jDdKbk.

Mishkin, Frederic S. (2001). The Transmission Mechanism and the Role of Asset Prices in Monetary Policy. NBER Working Paper 8617, December. http://www.nber.org/papers/w8617.

Mishkin, Frederic S. (2009). Is Monetary Policy Effective During Financial Crises? NBER Working Paper 14678, January. http://www.nber.org/papers/w14678.

Mishkin, Frederic S. (2010). Over the Cliff: From the Subprime to the Global Financial Crisis. NBER Working Paper 16609, December. http://www.nber.org/papers/w16609.

Morgan, Peter J. (2011). Impact of US Quantitative Easing Policy on Emerging Asia. ADBI Working Paper Series 321, November. http://econpapers.repec.org/paper/eabfinanc/23215.htm.

Ostry, J. D., Andrew, B., \& Charalambos, G. T. (2014). Redistribution, Inequality and Growth. IMF Staff Discussion Note, February. http://www.imf.org/external/pubs/ft/sdn/2014/sdn1402.pdf.

Ours, Jan van. (2015). How bad was the financial crisis, really? World Economic Forum. March 2. https://agenda.weforum.org/2015/03/how-bad-was-the-financial-crisis-really/?utm_content=buffer84550\&utm_me dium=social\&utm_source=twitter.com\&utm_campaign=buffer.

Parkinson, D. (2014). Debt risk, market turmoil threaten financial crisis. The Globe and Mail, September 9. http://www.theglobeandmail.com/report-on-business/are-we-on-the-verge-of-another-financial-crisis/article208508 10. 
Randow, J. (2015). Europe's QE Quandary. Bloomberg QuickTake, March 9. http://www.bloombergview.com/quicktake/europes-qe-quandary.

Roach, S. S. (2015). The Lemmings of QE. Project Syndicate. http://www.project-syndicate.org/commentary/ecb-quantitative-easing-experiment-by-stephen-s--roach-2015-01.

Roach, S. S. (2015). Why the global economy needs structural reform, not QE. World Economic Forum. April 30. https://agenda.weforum.org/2015/04/why-the-global-economy-needs-structural-reform-not-qe.

Schuman, M. (2008). Why Detroit is not Too Big to Fail? TIME. December 19. http://content.time.com/time/business/article/0,8599,1867847,00.html.

Shiratsuka, S. (2010). Size and Composition of the Central Bank Balance Sheet: Revisiting Japan's Experience of the Quantitative Easing Policy. Institute for Monetary and Economic Studies, Bank of Japan, Volume 28, November. http://www.imes.boj.or.jp/research/abstracts/english/me28-6.html.

Spence, M. (2015). Are Equities Overvalued? Project Syndicate. March 26.

http://www.project-syndicate.org/commentary/stock-market-equities-overvalued-by-michael-spence-2015-03.

Spiegel, M. M. (2006). Did Quantitative Easing by the Bank of Japan "Work"? FRBSF Economic Letter, 28, October 20. http://www.frbsf.org/economic-research/publications/economic-letter/2006/october/did-quantitative-easing-by-thebank-of-japan-work/el2006-28.pdf.

Stewart, H. (2013). Japan aims to jump-start economy with $\$ 1.4$ tn of quantitative easing. The Guardian, April 4. http://www.theguardian.com/business/2013/apr/04/japan-quantitative-easing-70bn.

Stibel, J. (2014). Why the Falling US Unemployment Rate Matters. Harvard Business Review.https://hbr.org/2014/11/why-the-falling-u-s-unemployment-rate-matters.

The Economist. (2015). Unfair Cop. The Economist. May 23. http://www.economist.com/news/leaders/21651822-americas-approach-punishing-financial-crime-muddled-lenient -and-self-defeating-unfair-cop.

Ugai, H. (2006). Effects of the Quantitative Easing Policy: A Survey of Empirical Analyses. Bank of Japan Working Paper Series 06-E-10, July. https://www.boj.or.jp/en/research/wps_rev/wps_2006/data/wp06e10.pdf.

Watkins, J. P. (2014). Quantitative Easing as a Means of Reducing Unemployment: A New Version of Trickle-Down Economics. Presented at the 2014 Annual Meetings Association for Evolutionary Economics, January 4.

Wolf, M. (2014). Monetary Policy: An Unconventional Tool. Financial Times, October 5. http://www.ft.com/intl/cms/s/0/22011490-4a30-11e4-8de3-00144feab7de.html\#axzz3c8jDdKbk.

\section{(cc) BY}

This work is licensed under a Creative Commons Attribution 3.0 License. 